\title{
Representação do trabalho escravo na mídia brasileira: relatos de estudo de recepção com trabalhadores rurais
}

\author{
Flávia de Almeida Moura. ${ }^{1}$
}

O estudo em andamento ${ }^{2}$ procura contribuir para as pesquisas no campo da Comunicação uma vez que tenta entender a mídia como um lugar de disputas discursivas que apresentam efeitos de sentidos no ato da recepção, neste caso, de um grupo social específico (trabalhadores rurais brasileiros que já passaram por condições de trabalho escravo contemporâneo ou são vulneráveis a elas).

O esforço para o desenvolvimento da pesquisa proposta está relacionado principalmente a uma busca pela compreensão da representação desse grupo social específico com os discursos midiáticos acerca deles. Buscamos entender como os trabalhadores recebem e se percebem nas informações sobre trabalho escravo contemporâneo bem como as interpretam (os seus variados sentidos).

Entendemos aqui a representação midiática sendo construída por vários outros discursos institucionais e organizados por uma "racionalidade" normativa, característica da própria mídia e não excluímos, num primeiro momento, que a representação dos próprios trabalhadores também possa influenciar a mídia, embora tenhamos o entendimento de que há discursos dominantes que podem suprimi-lo, apaga-lo ou ainda ressignificá-lo. Trabalhamos, neste primeiro momento, com o conceito de

\footnotetext{
${ }^{1}$ Professora Assistente do Departamento de Comunicação Social da UFMA.

${ }^{2}$ Trata-se do projeto de tese para doutoramento pelo Programa de Pós-graduação em Comunicação/ PUCRS com orientação da professora doutora Juliana Tonin.
}

Brasiliana - Journal for Brazilian Studies. Vol. 2, n.2 (Nov 2013). ISSN 2245-4373. 
representação em Stuart Hall (2003), uma vez entendido como um processo histórico, ideológico, cultural e político do indivíduo no seu contexto social.

A relevância do tema está em tentar entender, a partir do estudo de recepção com um grupo de trabalhadores maranhenses, a representação do trabalho escravo na mídia. Vale destacar que o Maranhão é um estado brasileiro historicamente apontado em estatísticas tanto nacionais quanto internacionais de maior incidência de trabalho escravo bem como na exportação de mão-de-obra submetida em regimes de escravidão contemporânea.

O presente artigo tem o objetivo de apresentar resultados do trabalho de campo realizado em Açailândia em agosto de 2013. Na ocasião, utilizamos a abordagem orientada pela metodologia do grupo focal (COSTA, 2008) para uma primeira aproximação com o tema junto a um grupo de oito trabalhadores que foram contactados e mediados pelo CDVDH/CB (Centro de Defesa da Vida e dos Direitos Humanos de Açailândia Carmen Bascáran), entidade de referência na região e reconhecida nacional e internacionalmente.

\section{Localização política e geográfica de Açailândia, Maranhão, Brasil}

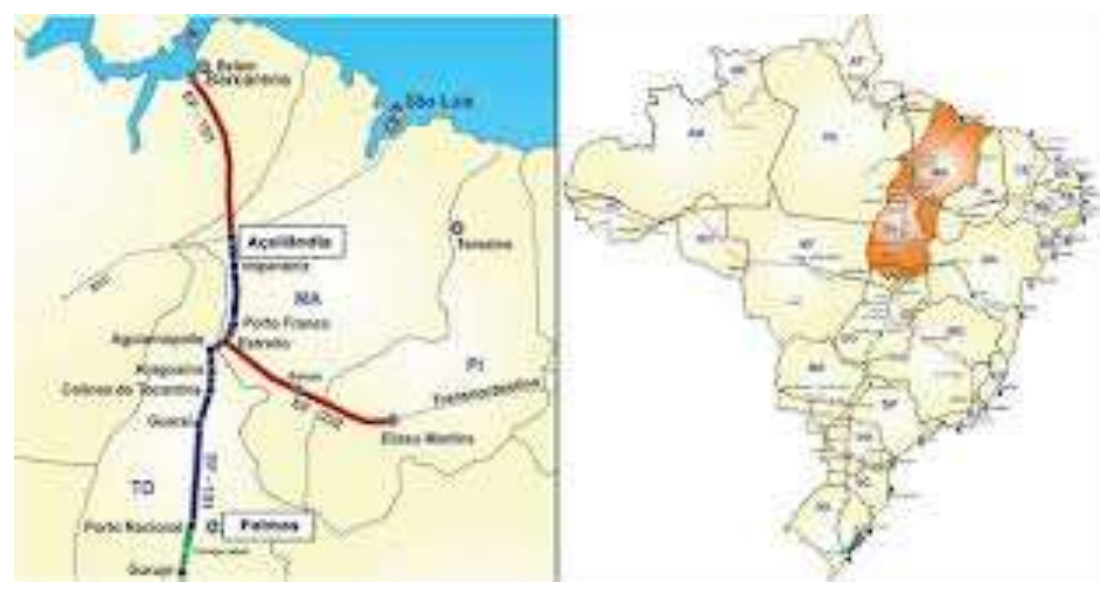

Brasiliana - Journal for Brazilian Studies. Vol. 2, n.2 (Nov 2013). ISSN 2245-4373. 


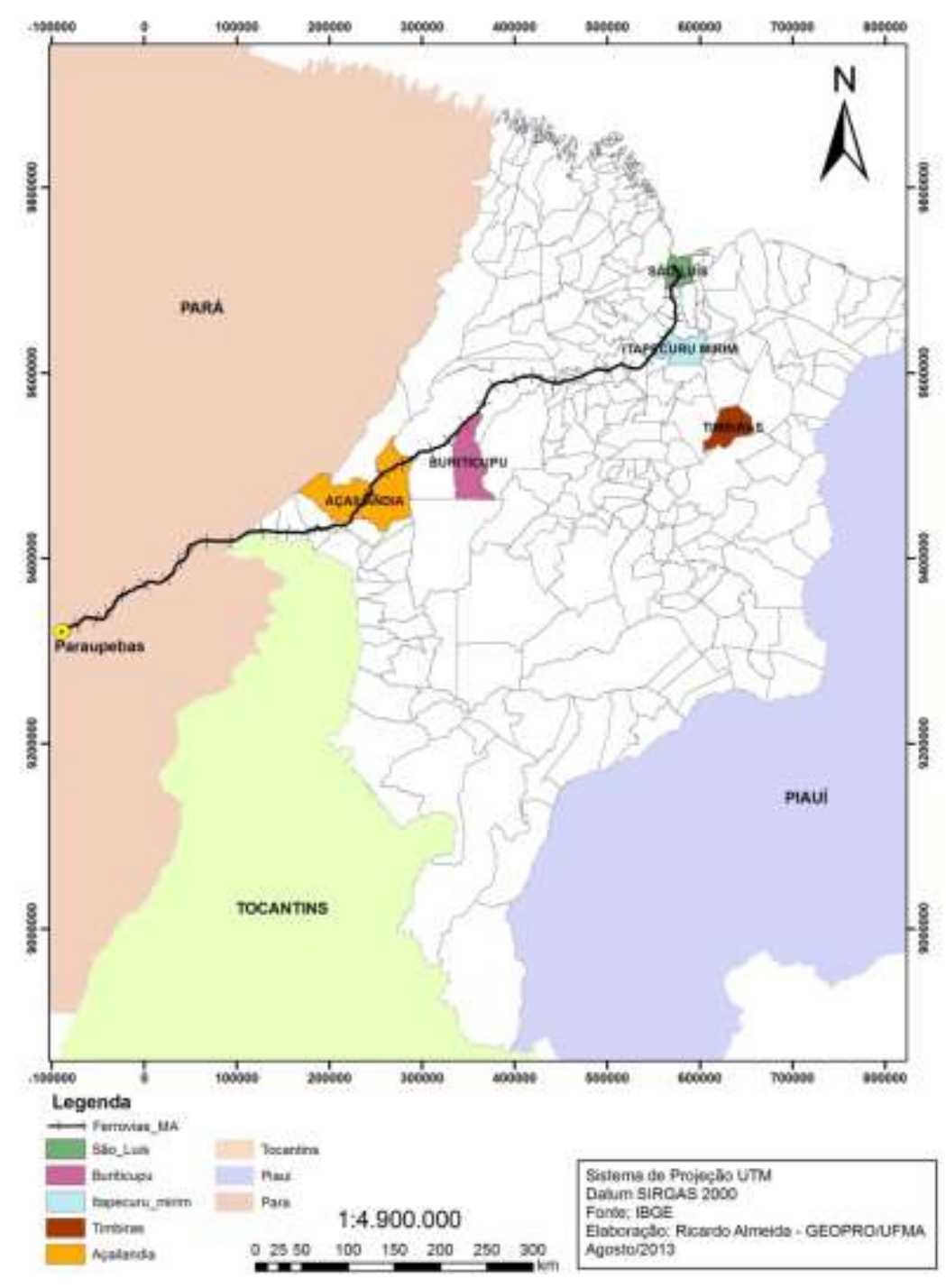

O município de Açailândia possui aproximadamente 5806 km², situado na Mesorregião Geográfica do Oeste Maranhense ${ }^{3}$. A importância dessa cidade deve-se à sua localização, em função de sua ligação com duas relevantes rodovias; a BR 222 e a BR 010 Belém-Brasília - construída no final dos anos 1950, e também por duas ferrovias

\footnotetext{
${ }^{3}$ Classificação utilizada pelo Instituto Brasileiro de Geografia e Estatística - IBGE.
}

Brasiliana - Journal for Brazilian Studies. Vol. 2, n.2 (Nov 2013). ISSN 2245-4373. 
importantes no Brasil: a Estrada de Ferro Carajás (unindo Parauapebas -PA ao Porto do Itaqui - MA) e a Ferrovia Norte Sul.

\section{Uma proposta de estudo de recepção: identificação dos informantes e das reportagens veiculadas durante trabalho de campo}

Partindo de uma classificação proposta por Ana Carolina Escosteguy (2004), entendemos o estudo de recepção a partir de uma abordagem "Sociocultural" ${ }^{4}$ uma vez que procura trabalhar a partir de uma visão complexa do processo de recepção dos produtos midiáticos levando em consideração relações sociais e culturais para problematizar o lugar do trabalhador escravo na mídia a partir de estudos teóricos (com base nos estudos de recepção) e empíricos (com contribuições da pesquisa qualitativa principalmente advinda da abordagem etnográfica ${ }^{5}$ na busca dos sentidos e representações sociais dos mesmos).

Como contribuição dos chamados estudos de recepção latino-americanos, entendemos que o conceito de mediações (MARTÍN-BARBERO, 1987) nos ajuda a pensar o lugar do trabalhador escravo na mídia ora como fonte/informante, ora como receptor/consumidor das informações. A obra "Dos Meios às Mediações", publicada em 1987, é revisitada pelo autor no ano de 1997; momento em que ele propõe que o título seja invertido, resultando em "Das Mediações aos Meios", indicando a necessidade, a partir da perspectiva econômica-cultural das novas tecnologias, de que os meios sejam

\footnotetext{
${ }^{4}$ Ao classificar os estudos realizados no Brasil acerca da recepção, Escosteguy (2004) identifica alguns tipos de abordagem nas pesquisas, como Sociocultural, Comportamental e Outras Abordagens.

5 "Dentro do quadro de incertezas epistemológicas, o interesse é analisar as estratégias de validação teóricometodológica que caracterizam a investigação etnográfica, os mecanismos e procedimentos de seleção dos eventos utilizados para estudo e o processo de abstração e integração dos resultados empíricos dentro de um sistema de generalização teórica" (GUEDES, 1998, p.108).
}

Brasiliana - Journal for Brazilian Studies. Vol. 2, n.2 (Nov 2013). ISSN 2245-4373. 
levados em conta na constituição das políticas culturais, a fim de que se enfrente o efeito dessocializador do neoliberalismo e se insira a indústria cultural no contexto econômico e político das regiões dos países latino-americanos.

Martín-Barbero (2003) discute que, através dos meios, legitima-se a onipresença mediadora do mercado, ou seja, alterando-se os sentidos das demandas políticas e culturais, deslegitimando-se os questionamentos da ordem social a qual o mercado, e a próprias tecnologias, permitem dar forma. $\mathrm{O}$ autor chama a atenção, também, para a manutenção da tensão, epistemológica e política, entre as mediações históricas que dotam os meios de sentido e alcance social e o papel de mediadores que eles possam estar desempenhando atualmente.

A contribuição de Martín-Barbero para esta investigação está relacionada ao entendimento da recepção como espaço de interação; como verdadeiro passo ante as mediações, o sentido e o tipo de mediações. Neste sentido, entendemos aqui que esse sujeito não pode ser tratado como vítima, isto é, "um ser manipulado, condenado ao que se quer fazer com ele"; mas sim como produtor de sentidos e capaz de ressignificar os discursos midiáticos (dele para a mídia enquanto fonte/emissor; dele na mídia como mensagem; dele sobre a mídia, enquanto receptor e ainda dele na sociedade, em suas rotinas cotidianas). Não pretendemos entender este sujeito apenas relacionando-o com os aparatos midiáticos, mas sim entender sua representação.

Assim, essa discussão se faz importante no que destaca a centralidade que os meios de comunicação ocupam, principalmente em países como os da América Latina, nos quais contrastam com os graves problemas sociais não solucionados, fragmentado a sociedade através do crescimento das desigualdades. Mais que as substituir, os meios passam a constituir as mediações, constituindo as cenas fundamentais da vida pública.

À luz de reflexões de Escosteguy e Jacks (2005), também acreditamos que as pesquisas de recepção precisam problematizar mais as respostas das audiências, pois 
são "algo que talvez não possa ser apresentado de forma tão clara e coerente" (Idem p. 93). Nesta linha de pensamento, entendemos o sujeito "trabalhador escravo" não como um todo homogêneo e, por isso, nos apropriamos de alguns estudos acerca do discurso para entender as suas contradições bem como as "inconsistências" dessas falas.

Além disso, não se pode esquecer que o sentido do fenômeno da recepção depende da maneira como se relaciona com os outros espaços do circuito cultural, em diversos momentos; desse modo, ele se articula com uma totalidade do processo de comunicação, situado num contexto histórico. (ESCOSTEGUY e JACKS, 2005, p. 94)

O relato presente neste artigo refere-se à primeira etapa do trabalho de campo deste projeto, na qual utilizamos a metodologia do grupo focal, uma vez que lança mão de instrumentos qualitativos (entrevista coletiva) que consegue recolher um maior número de informações num curto período de tempo (COSTA, 2005). A escolha pelo grupo focal está relacionada à dificuldade de encontrar os trabalhadores egressos do trabalho escravo $^{6}$ individualmente, sem suas residências, por serem considerados peões de trecho, isto é, trabalhadores sazonais que não costumam permanecer por muito tempo no mesmo local de trabalho e/ou moradia. Além disso, esses trabalhadores também não são, em geral, organizados em nenhuma instância sindical ou de classe. Diante da possibilidade de reunir um grupo de trabalhadores egressos do trabalho escravo por

\footnotetext{
${ }^{6}$ Trata-se de trabalhadores que foram encontrados em condições análogas a de escravos (Artigo 149 do Código Penal Brasileiro) e resgatados por equipes de fiscalização do MTE (Ministério do Trabalho e Emprego). Vale destacar que entendemos aqui trabalho escravo como uma categoria da Sociologia Brasileira que reúne uma série de características como condições sub-humanas de trabalho, locais precários de dormitório, alimentação inadequada e ainda cerceamento da liberdade a partir da dívida (ESTERCI, 1994).
}

Brasiliana - Journal for Brazilian Studies. Vol. 2, n.2 (Nov 2013). ISSN 2245-4373. 
intermédio do Centro de Defesa de Açailândia, aproveitamos a oportunidade do contato, portanto, de forma coletiva com os informantes.

Durante o trabalho de campo, assistimos ${ }^{7}$ junto aos informantes a 6 reportagens que tratam do tema e foram veiculadas pela televisão aberta brasileira nos últimos 5 anos. Os critérios de escolha das reportagens estão relacionados ao tempo de envolvimento dos informantes com a situação de trabalho escravo, uma vez que em sua maioria eles são jovens, na faixa etária entre 25 e 40 anos e tem, em geral, envolvimento com a questão há pelo menos 5 anos. Dentre os trabalhadores, um único é exceção. Tem 61 anos e esteve envolvido com questões relacionadas ao trabalho escravo em 2007, na Fazenda Por do Sol, em Bom Jardim (MA), de propriedade do juiz do Trabalho, Marcelo Baldoc. O caso teve repercussão nacional e ocupou mais de 9 minutos numa reportagem no Fantástico, em 2009. Este material compõe o corpus exibido aos trabalhadores durante estudo de recepção.

Vale destacar que, embora a metodologia do grupo focal tenha uma orientação clara de preservação da identificação dos participantes, preferimos, ao invés de utilizar números, identificar nossos informantes com os primeiros nomes. Essa decisão foi tomada junto deles, que concordaram com a proposta. Dessa forma, traçamos um breve perfil dos participantes (Ver Tabela 1) com informações de idade, local de origem, local de moradia e tipo de envolvimento com o trabalho escravo ${ }^{8}$.

\footnotetext{
${ }^{7}$ A equipe que aplicou a metodologia do grupo focal foi formada pela coordenadora do projeto e autora deste artigo, Flávia de Almeida Moura, bem como os alunos de iniciação científica Andréa Rabelo (Graduanda em Ciências Sociais), Antonio Paiva da Silva (Graduando em Relações Públicas), Liliane Cutrim e Matheus Coimbra (Graduandos em Jornalismo), todos da UFMA (Universidade Federal do Maranhão). Além dos estudantes, o grupo focal contou com a presença da agente do Centro de Defesa de Açailândia, Ivanete Silva, responsável pela articulação dos trabalhadores.

${ }^{8}$ Destacamos ainda as análises das falas dos informantes neste artigo não serão identificadas, mas sempre generalizadas em nosso texto (forma indireta) uma vez que os dados colhidos durante o trabalho de campo ainda estão em fase de sistematização e, portanto, seria apressado fazer quaisquer análises mais aprofundadas com trechos de falas específicos.
}

Brasiliana - Journal for Brazilian Studies. Vol. 2, n.2 (Nov 2013). ISSN 2245-4373. 


\section{Tabela 1: Identificação dos participantes}

\begin{tabular}{|c|c|c|c|c|}
\hline Nome & Idade & Local de origem & Local de moradia & $\begin{array}{l}\text { Envolvimento com o trabalho } \\
\text { escravo }\end{array}$ \\
\hline Ana Paula & 35 & Pinheiro (MA) & Açailândia (MA) & $\begin{array}{l}\text { Trabalhou como cozinheira na } \\
\text { Fazenda Sombra da Tarde por } 4 \\
\text { meses. Foi resgatada em } 2012 .\end{array}$ \\
\hline $\begin{array}{l}\text { José } \\
\text { Cipriano }\end{array}$ & 37 & $\begin{array}{l}\text { Palmerândia } \\
\text { (MA) }\end{array}$ & Açailândia (MA) & $\begin{array}{l}\text { Trabalhou na Fazenda Sombra da } \\
\text { Tarde com roço de juquira de } 2008 \text { a } \\
\text { 2012, quando foi resgatado. }\end{array}$ \\
\hline Marcos & 25 & Açailândia (MA) & Açailândia (MA) & $\begin{array}{l}\text { Trabalhou na Fazenda Sombra da } \\
\text { Tarde com roço de juquira por cerca } \\
\text { de } 6 \text { meses. Foi resgatado em } 2012 \text {. }\end{array}$ \\
\hline Raimundo & 61 & $\begin{array}{l}\text { Vargem Grande } \\
\text { (MA) }\end{array}$ & $\begin{array}{l}\text { Bom Jesus das } \\
\text { Selvas (MA) }\end{array}$ & $\begin{array}{l}\text { Trabalhou na Fazenda Por do Sol } \\
\text { em Bom Jardim (MA) durante } 4 \\
\text { meses, em 2007, quando foi } \\
\text { resgatado. }\end{array}$ \\
\hline Cristiano & 40 & $\begin{array}{l}\text { Palmerândia } \\
\text { (MA) }\end{array}$ & Açailândia (MA) & $\begin{array}{l}\text { Trabalhou na Fazenda Sombra da } \\
\text { Tarde com roço de juquira entre } \\
2008 \text { e 2012, quando foi resgatado. }\end{array}$ \\
\hline Gildásio & 33 & Monção (MA) & Açailândia (MA) & $\begin{array}{l}\text { Trabalhou na Fazenda Barbosa, em } \\
\text { Santa Luzia do Tide (MA) durante } \\
\text { quase } 6 \text { meses. Foi resgatado em } \\
2011 .\end{array}$ \\
\hline Antonio & 38 & Buriti Bravo (MA) & Açailândia (MA) & $\begin{array}{l}\text { Trabalha desde os } 15 \text { anos em } \\
\text { condições degradantes. Foi } \\
\text { resgatado } 3 \text { vezes no Maranhão e } \\
\text { Pará. No último trabalho } \\
\text { (carvoaria), sofreu acidente e } \\
\text { atualmente recebe auxílio doença } \\
\text { do governo. }\end{array}$ \\
\hline Marinaldo & 42 & Monção (MA) & $\begin{array}{l}\text { Pindaré Mirim } \\
\text { (MA) }\end{array}$ & $\begin{array}{l}\text { Trabalhou por quase } 4 \text { anos em } \\
\text { condições degradantes. Último } \\
\text { resgate foi em } 2012 \text { de uma fazenda } \\
\text { em Bom Jardim (MA), onde ele } \\
\text { roçava juquira. }\end{array}$ \\
\hline
\end{tabular}

Fonte: trabalho de campo 
Foram convidados para participar do grupo focal 12 trabalhadores e 8 deles participaram efetivamente das conversas ${ }^{9}$. O trabalho, realizado na sede do Centro de Defesa de Açailândia, foi dividido em dois momentos. Inicialmente, o grupo de pesquisadores juntamente com colaboradores do $\mathrm{CDVDH} / \mathrm{CB}$ receberam os trabalhadores, apresentando os objetivos da pesquisa e o funcionamento do grupo focal. Após as apresentações, foram realizadas algumas perguntas aos trabalhadores, no intuito de se ter uma visão geral do perfil de cada um, bem como a percepção deles sobre o trabalho escravo.

O objetivo era entender a representação deles como escravos. Num segundo momento, introduzimos a questão da mídia e a representação midiática sobre o trabalho escravo. Após um breve intervalo, numa proposta de estimulá-los a falar sobre o assunto, foram exibidas 6 reportagens veiculadas na TV aberta brasileira nos últimos 5 anos que tratam de questões relacionadas ao trabalho escravo e abrimos a discussão sobre o que foi assistido.

$\mathrm{Na}$ ocasião, foram realizadas algumas perguntas aos trabalhadores, buscando identificar a percepção deles sobre o conteúdo das matérias, se se sentiram representados, se houve identificação com o que foi apresentado, se as reportagens assistidas descrevem a realidade deles, etc, concluindo assim o grupo focal com os agradecimentos.

\footnotetext{
${ }^{9}$ Vale registrar que esse trabalho não teria sido possível sem a colaboração do Centro de Defesa de Açailândia, responsável pela articulação dos trabalhadores que eles acompanham após os resgates das fiscalizações de trabalho escravo na região.
}

Brasiliana - Journal for Brazilian Studies. Vol. 2, n.2 (Nov 2013). ISSN 2245-4373. 


\section{Tabela 2 - Reportagens exibidas durante grupo focal}

\begin{tabular}{|l|l|l|l|}
\hline Reportagem & Data de exibição & Emissora & Programa \\
\hline $\begin{array}{l}\text { Trabalho escravo no } \\
\text { Maranhão Açailândia } \\
\text { (denúncia de juiz do } \\
\text { trabalho) }\end{array}$ & $18 / 03 / 2009$ & TV Globo & Fantástico \\
\hline $\begin{array}{l}\text { Trabalho escravo no } \\
\text { corredor da Estrada de } \\
\text { Ferro Carajás }\end{array}$ & $26 / 06 / 2009$ & SBT & SBT Realidade \\
\hline $\begin{array}{l}\text { Pará lidera ranking de } \\
\text { trabalho escravo seguido } \\
\text { do MA, aponta lista suja }\end{array}$ & $06 / 07 / 2010$ & Record & Jornal da Record \\
\hline $\begin{array}{l}\text { Sudoeste do Maranhão } \\
\text { convive com a violência } \\
\text { no campo }\end{array}$ & $25 / 05 / 2012$ & TV Globo & Jornal Nacional \\
\hline $\begin{array}{l}\text { Hoje é o Dia Nacional de } \\
\text { Combate ao Trabalho } \\
\text { Escravo (trabalho do } \\
\text { CDVDH/CB) }\end{array}$ & $28 / 01 / 2013$ & TV Globo & Bom dia Maranhão (local) \\
\hline $\begin{array}{l}\text { Parte 1 - A Liga sobre } \\
\text { Trabalho Escravo Rural e } \\
\text { Urbano }\end{array}$ & $16 / 08 / 2011$ & TV Bandeirantes & $\begin{array}{l}\text { A Liga (Programa de } \\
\text { reportagem) }\end{array}$ \\
\hline
\end{tabular}

Fonte: pesquisa documental

Durante as conversas, percebemos que os materiais escolhidos para a exibição eram conhecidos de parte dos informantes, embora tenham todos sido veiculados em rede aberta de televisão brasileira e em canais de fácil acesso aos mesmos. Vale destacar que todos afirmaram possuir aparelhos de televisão em suas residências.

Também percebemos que os trabalhadores não apresentam periodicidade definida para assistir a programas de televisão, uma vez que são ocupados com trabalhos rurais ou em locais isolados (às vezes longe dos locais de moradia); o que os impede, na maioria das vezes, de serem receptores frequentes. Apesar disso, notamos que eles consomem os conteúdos veiculados pela televisão, por vezes, de formas indiretas, isto é, a partir de conversas com amigos e familiares, principalmente filhos e esposas, que assistem televisão com maior frequência que eles. 
Dentre os 8 integrantes do grupo focal, apenas uma é mulher (Ana Paula). Tratase da esposa de um dos trabalhadores que aceitou o trabalho de cozinheira e acabou sendo submetida a regimes de escravidão juntamente com o marido ${ }^{10}$. Outra exceção é um trabalhador (Antonio) que foi resgatado em 2011 após ter sofrido um acidente de trabalho numa carvoaria no Pará e encontra-se atualmente recebendo benefício do governo federal relacionado a auxílio-doença, portanto, como eles costumam dizer, "está encostado" em casa, sem trabalhar. Neste caso, nota-se que esses dois informantes apresentam uma situação diferente dos demais e, portanto, assistem televisão com mais frequência.

\section{A questão da representação dos trabalhadores: análises preliminares}

Segundo Hall (2010), representação significa usar a linguagem para dizer algo com sentido sobre o mundo ou para representá-lo de maneira significativa para as outras pessoas. Dessa forma, a representação é entendida como uma parte essencial do processo mediante o qual se produz e troca sentidos entre os membros de uma mesma cultura. Representar implica no uso da linguagem, dos signos e das imagens que estão no lugar das coisas, que as representam. Mas o autor ressalta: não trata-se de um processo direto e simples.

Como dito anteriormente, no primeiro momento do grupo focal, tratamos sobre a representação que os trabalhadores tem acerca do trabalho escravo. Alguns afirmaram que conheceram a escravidão em trabalhos que realizaram em fazendas de gado e

\footnotetext{
${ }^{10}$ Vale destacar que segundo as estatísticas da fiscalização do MTE (Ministério do Trabalho e Emprego), os trabalhadores submetidos a essas condições são, em grande maioria, do sexo masculino, apresentando algumas exceções, como no corte de cana ou em outras atividades que não estão diretamente relacionadas à realidade do Maranhão, cujas principais atividades econômicas envolvidas são o chamado "roço da juquira" (limpeza de pasto para criação de gados) e atividades relacionadas ao carvoejamento (carvoarias).
}

Brasiliana - Journal for Brazilian Studies. Vol. 2, n.2 (Nov 2013). ISSN 2245-4373. 
carvoarias do Maranhão bem como outros estados próximos, como Pará e Tocantins, onde as condições eram muito precárias tanto de higiene, de alimentação e dormitório, além da violência física e psicológica por parte dos empreiteiros, aliciadores e mesmo gerentes dos estabelecimentos. (Como aponta a Figura 1, que indica trecho de reportagem exibida pela TV Bandeirantes no programa A Liga, em 2011, na qual um trabalhador é entrevistado por uma auditora fiscal do trabalho no alojamento precário de uma carvoaria no Pará)

\section{Figura 1: Trecho de reportagem exibida pela A Liga (TV Bandeirantes), em 2011}

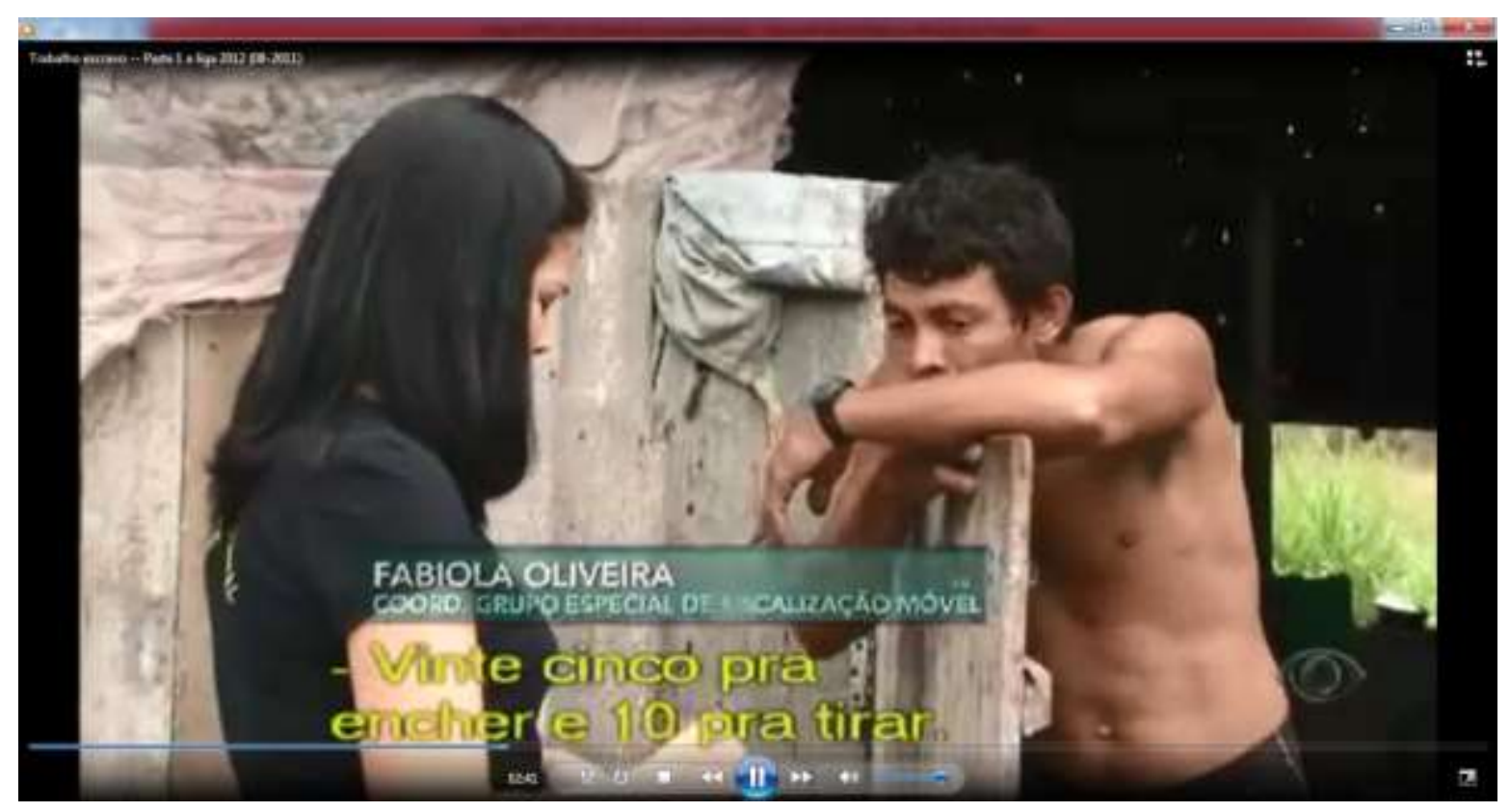

Fonte: pesquisa documental

Em geral, percebemos que a auto-representação de "trabalhador escravo" se dá a partir de um contato com os mediadores seja do movimento social (que informam a eles sobre os seus direitos) seja do governo, como é o caso mais frequente dos auditores fiscais do trabalho que participam de ações de fiscalização e identificam nos locais regimes de trabalho escravo. Dificilmente ela se dá antes desse contato, até porque eles tem uma 
visão de que "o trabalho na roça é duro" ou ainda não se identificam com esse termo, já que está mais relacionado no imaginário da maioria com o tráfico negreiro e o período colonial. Sobre isso, Esterci (2004) prefere chamar essa situação de servidão por dívida ou peonagem, para diferenciar dessa prática do século 19.

Buscando conectar os conceitos de representação ao sentido, à linguagem e à cultura, Stuart Hall (2010) afirma que representação é a produção de sentido dos conceitos em nossa mente mediante a linguagem. Para ele, o vínculo entre os conceitos e a linguagem é o que nos capacita para distinguirmos o mundo real dos objetos; as pessoas dos eventos, entre outros. O que Hall chama de "sistemas de representação" são diferentes modos de organizar, agrupar e classificar conceitos e de estabelecer relações complexas entre eles, utilizando os princípios de semelhanças e diferenças também para distinguir uns dos outros. O sentido sempre depende da relação entre as coisas no mundo - pessoas, objetos e eventos reais ou fictícios - e é o que forma as "representações mentais", resultando nos "mapas conceituais", responsáveis por auxiliar os grupos sociais a interpretar o mundo; que vai compor o que o autor denomina de "sistemas de sentidos na cultura".

Para Hall (2010), a relação entre os sistemas de representação (signo, conceito e objeto) é arbitrária; isto é, o sentido não está no objeto, na pessoa ou na coisa, nem tampouco na palavra. O sentido é construído pelo sistema de representação; a partir de códigos compartilhados. Pertencer a uma cultura é pertencer ao mesmo universo conceitual e linguístico; é saber como conceitos e ideias se traduzem a diferentes linguagens e como a linguagem se refere. Compartilhar essas coisas é ver o mundo pelo mesmo mapa conceitual e dar sentido a ele mediante o mesmo sistema de linguagem.

Nesta perspectiva, nos interessamos em adentrar nos sentidos desse grupo social que, apesar de viver na contemporaneidade e receber as informações da mídia tradicional via televisão, apresenta-se com características muito específicas. 
Parafraseando Hall, apresentam mapas conceituais próprios e diferentes dos nossos e, consequentemente, uma linguagem também distinta. Como adentrar nesse universo, nesse sistema de representação do trabalho escravo a partir dos trabalhadores para, daí, partirmos para compreender a representação midiática acerca deles?

\section{Figura 2: Trecho de reportagem exibida no Jornal Nacional, em 2012}

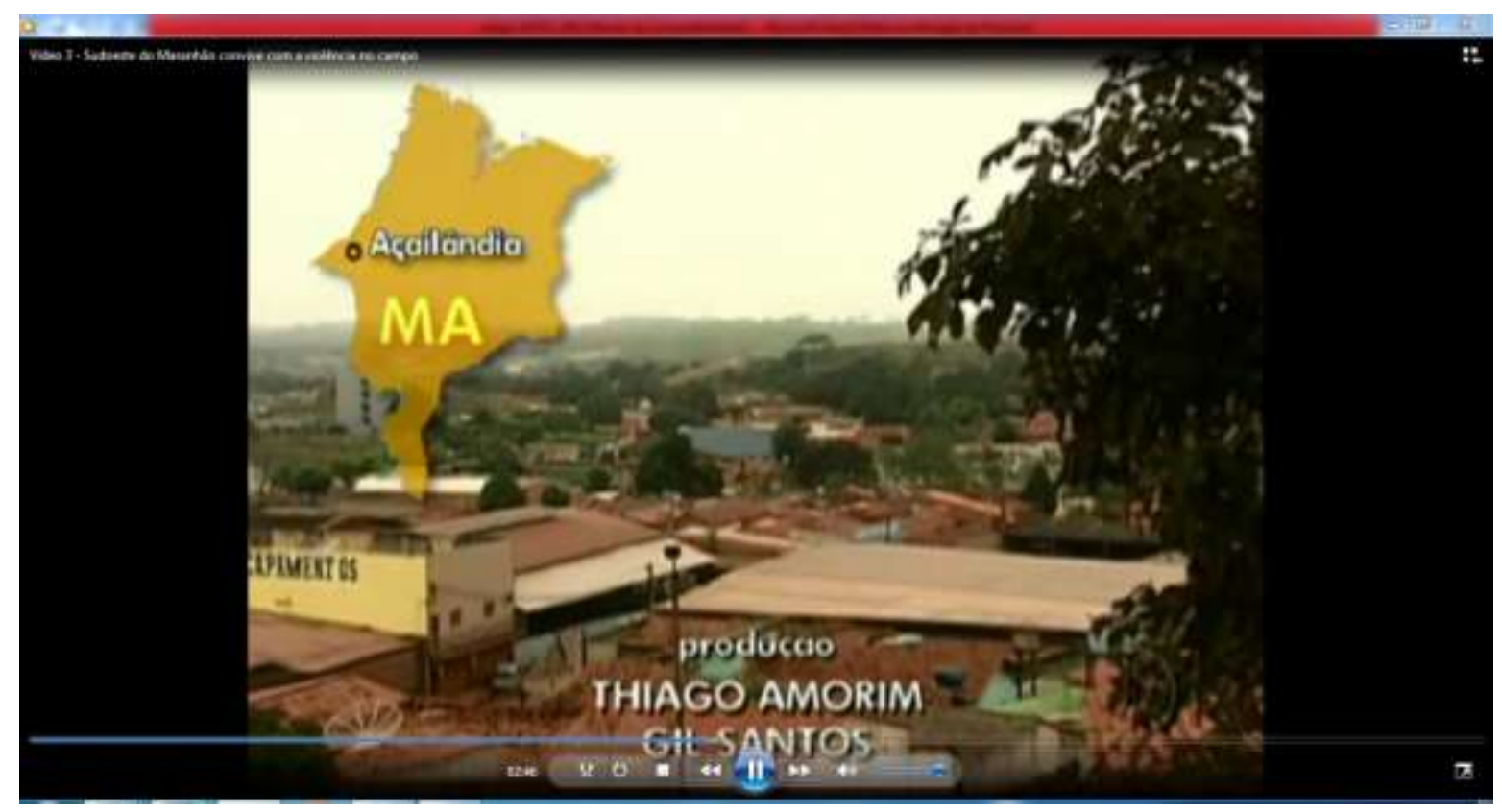

Fonte: pesquisa documental

Sobre os materiais exibidos durante o segundo momento do grupo focal, os trabalhadores afirmaram que não costumam assistir com tanta intensidade, principalmente às reportagens que dão voz a eles. Eles estão mais acostumados ver pessoas falando deles ou sobre eles, como auditores do Ministério do Trabalho e Emprego, operadores do Direito ou ainda agentes do movimento social.

Eles afirmaram ainda que já tiveram contato com institucionais que tratam da questão, como por exemplo, da Campanha Coração Azul (promovida por organizações internacionais com enfoque no Brasil contra o trabalho escravo e o tráfico de pessoas) e do Movimento Humanos Direitos (MhuD), uma ONG de artistas e intelectuais do Rio 
de Janeiro que produziram spots institucionais veiculados pelo Globo Cidadania em 2011 e 2012 (Ver Figura 3). Apesar de entendermos que necessitamos de mais investigação para analisar essa recepção, inferimos que esse material chegou até os trabalhadores principalmente por ser veiculado na grade de programação principalmente nos intervalos comerciais das novelas da Rede Globo.

\section{Figura 3: Trecho de vídeo institucional do MhuD, gravado pelo ator Wagner Moura}

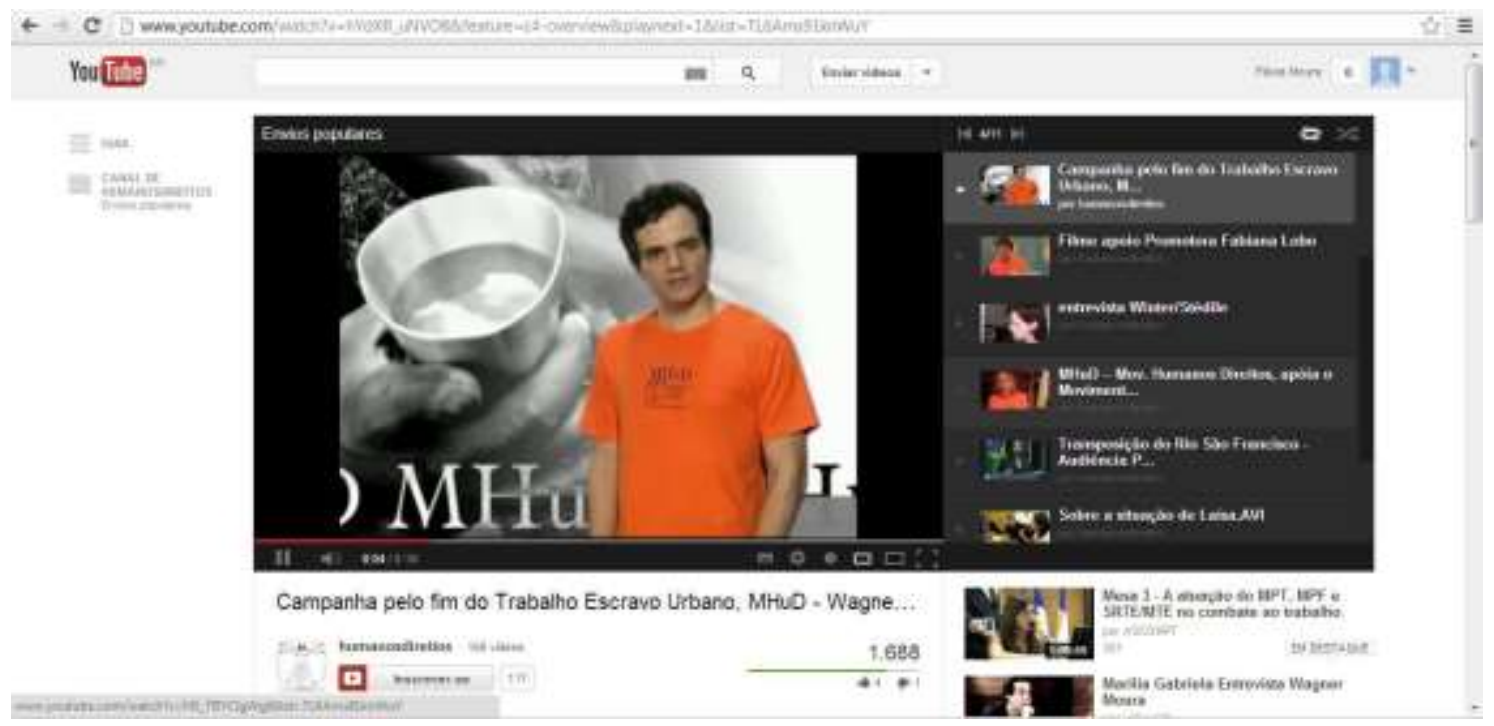

Fonte: pesquisa documental

A partir desse entendimento, questionamos nossos informantes sobre quais os principais programas assistidos por eles. Embora as respostas tenham sido bem genéricas e pouco precisas, as telenovelas e os programas de auditório aparentemente ocupam mais o tempo deles do que os telejornais; foco principal de nossas exibições (material jornalístico). Aqui, com exceção do programa Fantástico, da Rede Globo, exibido aos domingos à noite, e que mistura jornalismo com entretenimento, e que eles também informaram que assistem. 
Ainda sobre o conceito de representação, Hall (2010) entende as imagens como signos que possuem sentidos e, portanto, são passíveis de interpretação. Para isso, segundo o autor, é necessário acessar dois sistemas de representação compostos por (1) um mapa conceitual que relacione a coisa com a sua representação bem como (2) um sistema de linguagem que tenha alguma semelhança com a coisa real que se quer representar.

Sobre esse aspecto, daremos continuidade à nossa investigação, uma vez que não conseguimos ainda captar dos trabalhadores se a linguagem utilizada na mídia (o discurso midiático) para representá-los faz sentido a eles ou ainda até que ponto os representa.

Durante o grupo focal, após a exibição das reportagens, perguntamos aos nossos informantes se eles se sentiram representados. Em geral, a resposta foi positiva, embora alguns tenham apresentado aspectos que não são tratados, em geral, em reportagens sobre o assunto e que, na prática, eles vivem ou viveram. Um aspecto, por exemplo, apresentado pelo grupo como algo que falta na abordagem das matérias jornalísticas está ligado ao uso de drogas nos locais de trabalho, principalmente maconha, mas também do crack e de bebidas alcóolicas até mesmo como formas de pagamento aos trabalhadores que acabam consumindo para "aguentar o trabalho duro". Alguns relatos informam ainda que bebidas e drogas também constam nos caderninhos que os aliciadores anotam dos gastos dos trabalhadores, juntamente com alimentação, ferramentas de trabalho entre outros, o que mantém as dívidas.

Outro aspecto interessante observado durante o grupo focal foi a reação dos trabalhadores contrários às falas dos empregadores nas reportagens, do tipo "é tudo mentira o que eles falam; que tem alojamento, que tem boa alimentação".

Ainda sob orientação dos estudos que analisam discursos como enunciação e práticas sociais, buscamos entender o chamado "silenciamento" ou o silêncio do 
discurso (ORLANDI, 2007), no caso principalmente do trabalhador escravo em detrimento ao discurso midiático e dos mediadores.

Há um modo de estar no silêncio que corresponde a um modo de estar no sentido e, de certa maneira, as próprias palavras transpiram silêncio. Há silêncio nas palavras (...) o estudo do silenciamento (que já não é silêncio, mas 'pôr em silêncio') nos mostra que há um processo de produção de sentidos silenciados que nos faz entender uma dimensão do não-dito absolutamente distinta da que se tem estudado sob a rubrica do 'implícito. (ORLANDI, 2007, p.11-12)

Orlandi (2007) afirma que o silêncio foi relegado a uma posição secundária, como o "resto" da linguagem. Em contraposição a isso, ela afirma que há sentido no silêncio e que todo dizer é uma relação fundamental com o não-dizer. A partir desta orientação, buscaremos investigar se há silenciamento que limita o sujeito (trabalhador escravo) no percurso dos sentidos na mídia, isto é, se o discurso midiático nega este sujeito (receptor) como interlocutor ou impede que as palavras deles façam sentido.

Sobre este assunto, Marilda Amorim (2004) nos ajuda a entender a proposta de Mikhail Bakthin ao tentar ultrapassar a ideia segundo o qual o conhecimento é uma questão de voz, mas valendo-se de que o conhecimento que se produz no texto (e na interlocução) também é uma questão de silêncio (voz silenciada ou ausência de voz).

Mas tanto pela voz como pelo silêncio estaremos às voltas com produção de sentidos. É portanto a espessura discursiva que se coloca aqui como horizonte e como limite de análise do texto da pesquisa, pois 
a construção do sentido de todo discurso é, por definição, inacabável. (AMORIM, 2004, p. 19)

Neste caso, a sensação de que a voz do empregador é sempre privilegiada na reportagem, segundo os informantes, é atrelada à edição do material jornalístico, uma vez que eles apontam que a maioria das reportagens termina com as falas dos empregadores se justificando ou mesmo dizendo que a situação encontrada não era de trabalho escravo.

Norman Fairlclough (2001), influenciado pelos estudos culturais britânicos, também nos auxilia nesta análise ponto que estuda a influência das relações de poder sobre o conteúdo e a estrutura dos textos, no nosso caso, com interesse sobretudo nos discursos midiáticos. Para ele, ao usar o termo discurso, há uma proposta de considerar o uso de linguagem como forma de prática social e não como "atividade puramente individual ou reflexo de variáveis situacionais".

Fairclough entende discurso como (1) modo de ação, como (2) forma de representação, como (3) identidade, como relação social (relacional) (4) e como construção de sistemas de conhecimentos e crenças (5) (ideacional). Neste contexto, o autor defende o discurso como transformação social.

A prática discursiva é constitutiva tanto de maneira convencional como criativa: contribui para reproduzir a sociedade (identidades sociais, relações sociais, sistemas de conhecimento e crença), como é, mas também contribui para transformá-la.(...) É importante que a relação entre discurso e estrutura social seja considerada como dialética para evitar os erros de ênfase indevida: de um lado, na determinação social 
do discurso e, de outro, na construção social do discurso. (FAIRCLOUGH, 2001, p.92)

Interessamos por esta discussão do discurso como transformação social ao analisar sujeitos da recepção e do consumo também como produtores de discursos, capazes de transformar ou passíveis de serem transformados e ressignificados pela mídia. E por isso, nos propomos a buscar entender como esses discursos midiáticos são recebidos por esse grupo de trabalhadores.

\section{Considerações finais}

Buscando compreender a representação percebida pelos trabalhadores rurais brasileiros sobre o trabalho escravo na mídia, optamos por fazer um estudo de recepção junto a um grupo trabalhadores rurais egressos do trabalho escravo. Este artigo apresentou parte dos dados colhidos durante a primeira etapa do trabalho de campo composta por uma entrevista coletiva (grupo focal) com um grupo de 8 trabalhadores, realizada na sede do Centro de Defesa de Açailândia.

Procuramos entender inicialmente a representação dos trabalhadores envolvidos na questão bem como analisar as suas produções de sentido e/ou interpretações, levando em consideração que há um discurso dominante (midiático), mas que não "abstrai" o discurso da recepção, que compreende o assunto a partir de seu repertório.

Como resultados do grupo focal, pode-se afirmar que os trabalhadores se sentem representados pelas reportagens, embora elas não contemplem todos os aspectos da realidade vivida por eles, como indicamos anteriormente as questões relacionadas ao uso de bebidas e drogas nos locais de trabalho e até mesmo o pagamento aos 
trabalhadores com essas substâncias, além da violência física e psicológica que eles afirmam ter passado nos locais de trabalho e não tratado nas reportagens ${ }^{11}$. Outro aspecto a ser trabalhado é a forma com que esses trabalhadores recebem essas informações veiculadas pela televisão na sua cotidianidade familiar (BARBERO, 2001), uma vez que identificamos que nem todos tem contato direto e periódico com o discurso midiático. Talvez esse fator possa ser interessante para encaminharmos a pesquisa daqui pra frente numa perspectiva não de entender exatamente como eles se veem na televisão, mas sim como eles percebem o discurso midiático sobre eles, uma vez que os mesmos não se veem cotidianamente pela tela.

\section{Referências Bibliográficas}

Amorim, Marília. O pesquisador e o seu outro. Bakhtin nas Ciências Humanas. Musa Editora, São Paulo, 2004.

Costa, Maria Eugênia Belczak. Grupo focal. In: Duarte, Jorge; Barros, Antonio (org.). Métodos e técnicas de pesquisa em Comunicação. Atlas, São Paulo, 2005.

Escoteguy, Ana Carolina D. Notas para um estado da arte sobre os estudos brasileiros de recepção nos anos 90. In Machado, J; Lemos, A; Sá, S (orgs) Mídia.BR, Sulinas, Porto Alegre, 2004.

. Estudos culturais: uma introdução. In Silva, T.T. O que é afinal estudos culturais? Autêntica Editora: Belo Horizonte, 2010.

Esterci, Neide. Escravos da Desigualdade: estudo sobre o uso repressivo da força de trabalho hoje. Cedi :Rio de Janeiro, 1994.

\footnotetext{
${ }^{11}$ Aqui também precisamos ponderar que outras reportagens que não exibidas neste momento já trataram sobre esse assunto de assédio moral e mesmo violência física e psicológica junto aos trabalhadores. Mas a questão do pagamento com drogas, não temos conhecimento de matérias jornalísticas que tenham tratado do assunto anteriormente. Neste sentido, estamos em fase de pesquisa documental para tentar identificar dentro, de nossas possibilidades, se algum material jornalístico já tenha tocado nesse assunto.
}

Brasiliana - Journal for Brazilian Studies. Vol. 2, n.2 (Nov 2013). ISSN 2245-4373. 
Fairclough, Norman. Discurso e mudança social. Editora Universidade de Brasília, Brasília, 2001.

Guedes, Olga. Os estudos da recepção: etnografia e globalização. In Rubim, A.A.C; Bentz, I. M. G; Pinto M. J (org) Produção e recepção dos sentidos midiáticos. Vozes, Petrópolis, Rio de Janeiro, 1998.

Hall, Stuart. Da diáspora: Identidades e mediações culturais. UFMG, Belo Horizonte, 2003.

- Sin garantias: Trayectorias y problemáticas en estudios culturales. Perú/Colômbia/Ecuador, 2010.

Jacks, Nilda. (org) Meios e audiências: a emergência dos estudos de recepção no Brasil. Sulinas: Porto Alegre, 2008.

Martín-Barbero, Jesús. Dos meios às mediações: comunicação, cultura e hegemonia. Editora UFRJ, Rio de Janeiro, 2001. América Latina e os anos recentes: o estudo da recepção em comunicação social. In Sousa, M. W. (org) Sujeito, o lado oculto do receptor. Brasiliense, São Paulo, 1995.

. Tecnicidades, identidades, alteridades: mudanças e opacidades da comunicação no novo século. In: Moraes, Dênis (org.). Sociedade midiatizada. Mauad, Rio de Janeiro, 2006.

. Pistas para entre-ver meios e mediações. Dos meios às mediações - Comunicação, cultura e hegemonia. Prefácio à $5^{\text {a }}$ edição castelhana incluída na reimpressão. Editora UFRJ, Rio de Janeiro, 2003.

Orlandi, Eni Puccinelli. As formas do silêncio: no movimento dos sentidos. Editora da Unicamp, Campinas, 2007. 